\title{
"Ibizagate": Capturing a Political Field in Flux
}

\author{
Christian Karner \\ School of Social and Political Sciences, University of Lincoln, Lincoln, UK \\ Email: CKarner@lincoln.ac.uk
}

\begin{abstract}
The "Ibiza affair," a succession of scandals triggered by undercover recordings of the FPÖ's former head, Heinz-Christian Strache, in compromising discussions with a purported Russian oligarch's niece has profoundly altered Austria's political landscape and public debates. This article offers a historically contextualized analysis of the multiple voices and competing truth claims articulated by diverse actors in the course of the scandal's fallout. Empirically, this discussion offers a systematic analysis of political and media discourses focused on "Ibiza" between May 2019 and June 2020. Conceptually, the argument builds on Michel Foucault's approach outlined in I, Pierre Rivière and its subsequent applications within nationalism studies. This analysis thus examines data through the questions as to who speaks about the event in question, how they do so, what is being claimed and disputed, and which political strategies and trajectories this enables. The competing, partly shifting positions revealed are the following: Strache's initial regret that soon turned to a selfascribed "victim-cum-martyr" status; the FPÖ's distancing and eventual rupture from its long-standing Bundesparteiobmann; the Kronen Zeitung's attempted ideological repositioning; the ÖVP's need and opportunity to shift its positions vis-à-vis its political competitors; and critical voices calling for far-reaching structural changes. With the full facts behind the scandal still to be established, the (post-Foucauldian) approach applied here captures the contestations, (new) fault lines, and (shifting) political boundaries constitutive of a discursive field in a crisis context.
\end{abstract}

Keywords: Austria; FPÖ; Ibizagate; nationalism; Michel Foucault; political crisis

In May 2019, Austria was engulfed in arguably the biggest scandal since the Waldheim affair ${ }^{1}$ of 1986. Now known as "Ibiza," this scandal revolved around then vice-chancellor and head of Austria's farright Freiheitliche Partei Österreichs (FPÖ), Heinz-Christian Strache. Undercover video recordings had been made available to, and reports published by, journalists writing for the German daily Süddeutsche Zeitung and the weekly newsmagazine Der Spiegel. The video recording showed Strache and his FPÖ colleague Johann Gudenus in a villa on the Spanish island of Ibiza nearly two years previously, in July 2017, in compromising conversations with a woman posing as a Russian oligarch's niece. The secret recording revealed discussions about potential favors Strache was apparently willing to offer in exchange for possible hidden financial support and the pretend-oligarch's niece's possible (partial) "takeover" of Austria's most widely read newspaper. ${ }^{2}$ Unbeknownst to them, Strache and Gudenus had walked into a trap that revealed deep contradictions between the FPÖ's self-styled image as an anticorruption, antiestablishment party and the lengths to which Strache and Gudenus were seemingly prepared to go, or at least to entertain, in the pursuit of power.

\footnotetext{
${ }^{1}$ Richard Mitten, The Politics of Antisemitic Prejudice (Boulder, 1992).

${ }^{2}$ There was talk about nondeclared donations-not to the party but to ideologically aligned associations-which Strache euphemistically described as gemeinnützige Vereine; see Der Spiegel, "Die Videofalle," 17 May 2019, https://www.spiegel.de/ video/fpoe-chef-heinz-christian-strache-die-videofalle-video-99027174.html. Subsequent reports suggested that there were indeed indications that such donations may have taken place; see "Bericht: Großspenden von Industriellen an FPÖ-nahe Vereine," ORF News, 19 Feb. 2020, https://www.orf.at/stories/3154929/.

(c) The Author(s), 2021. Published by Cambridge University Press on behalf of the Center for Austrian Studies, University of Minnesota. This is an Open Access article, distributed under the terms of the Creative Commons Attribution licence (http://creativecommons.org/licenses/by/4.0/), which permits unrestricted re-use, distribution, and reproduction in any medium, provided the original work is properly cited.
} 
The ensuing fallout has changed Austria's political landscape. When the scandal broke, shortly before the European elections, Austria was governed by a coalition between the center-right People's Party (ÖVP) and the FPÖ. In less than eighteen months, this government had moved issues associated with the FPÖ's nationalist agenda to the center of its policy remit. Such issues included asylum and its discursive tying to questions of security and criminality, ${ }^{3}$ immigration and integration, and attempts to resist further European integration or undo some of its existing manifestations. ${ }^{4}$ Concurrently, individual FPÖ politicians had made news with xenophobic outbursts or their documented proximity to far-right civil society associations. ${ }^{5}$ Chancellor Sebastian Kurz (ÖVP) had on several occasions struggled to maintain his party's coalition with a partner that showed no qualms about such entanglements. In the wake of breaking news about Strache's secretly recorded conversations on Ibiza, this proved no longer possible. Within hours, Strache and Gudenus had resigned. Within days, the coalition was no more. Soon thereafter, Kurz's attempt to continue as chancellor ended abruptly following the Second Republic's first successfully passed vote of no confidence in parliament, initiated by the Social Democrats (SPÖ) and, remarkably, supported by the FPÖ that had only just left the coalition. These most extraordinary days in recent Austrian history saw a newfound popularity enjoyed by Federal President Alexander Van der Bellen, who steered Austrian politics through these unprecedented circumstances. ${ }^{6}$ Van der Bellen credited the constitution for providing the necessary guidance and nominated a "caretaking" government comprised of experts and high-profile civil servants until snap elections in late September 2019. With 37.46 percent of the vote, Sebastian Kurz emerged from those once again victorious, the SPÖ dropped to 21.18 percent, the FPÖ suffered massive losses (i.e., 16.17 percent, compared to 25.97 percent two years previously), while the Greens (13.9 percent) secured their return to parliament and the liberal, pro-European NEOS increased their share of the vote to 8.1 percent. In January 2020, the ÖVP and the (unambiguously left-leaning) Greens formed Austria's next coalition government. ${ }^{7}$

This sketches the contours of events in Austria after May 2019, but the fallout of the Ibiza affair went further. Not only did it temporarily end two political careers, namely Strache's and Gudenus's, it also triggered a series of subsequent, related revelations. Investigations into the people behind (Hintermänner) the recording continue at the time of writing. The electoral "hit"-on regional, national, and European levels-taken by the FPÖ has been formidable, although not as large as some had predicted. In the months since the scandal broke, it has featured prominently in Austrian political discussion and media discourse. This article traces the fault lines that emerged or deepened in the aftermath of the scandal(s) and through the various argumentative positions adopted by a range of actors debating and pronouncing on the issue. What follows is not an attempt to establish a definitive verdict of what happened on Ibiza, its illegality, and consequences. At the time of completing this article, the scandal is the object of a parliamentary inquiry, and the full facts of the matter are far from established. Instead, this analysis offers a Foucauldian reading of a still unfolding scandal and the discursive field of competing positions to which it has given rise. Analysis of the various truth claims formulated in this contested discursive field reveals dynamics that are partly (re)shaping Austria and the self-understandings of key actors implicated.

The argument unfolds in successive steps. A summary of the theoretical genealogy on which this article draws is followed by historical contextualization and by outlines of the corpus of data underpinning this discussion and the analytical strategy driving it. The main sections document competing argumentative positions that have shaped, and continue to shape, the discursive field that has opened up in the aftermath of the Ibiza scandal. By reading those positions as competing truth and identity

\footnotetext{
${ }^{3}$ Michał Krzyżanowski and Ruth Wodak, The Politics of Exclusion (New Brunswick, 2009), 6.

${ }^{4}$ Christian Karner, Nationalism Revisited: Austrian Social Closure from Romanticism to the Digital Age (New York, 2020$), 210$.

${ }^{5}$ Julian Bruns, Kathrin Glösel, and Natasha Strobl, Die Identitären (Münster, 2017).

${ }^{6}$ Former Green politician Alexander Van der Bellen had won the presidential campaign in 2016 following an antagonistic runoff against the FPÖ's Norbert Hofer, who in 2019 became Strache's successor at the FPÖ's helm.

${ }^{7}$ Sebastian Kurz has thus formed successive coalitions, at first with the far-right FPÖ and now with a partner on the opposite end of the spectrum.
} 
claims in their wider contexts, a novel perspective on contemporary Austria, and more narrowly on the (shifting) discursive positions represented by prominent actors in its public domain, becomes possible.

\section{Contexts: Theoretical, Historical, Methodological}

Conceptually, this discussion builds on I, Pierre Rivière, in which Michel Foucault and his colleagues examine the competing discourses and implicated truth claims made by medical, psychiatric, and legal actors surrounding the 1835 trial of Pierre Rivière. The latter stood accused of murdering his mother and siblings, before taking flight and being apprehended near his village in Normandy. Drawing on a range of documents (court transcripts, police reports, etc.), Foucault et al. ${ }^{8}$ demonstrate how the establishment of "the facts" surrounding a gruesome crime implicated diverse actors and institutions vying for hermeneutical hegemony in a contest over truth, responsibility, and the institutionalized authority to define both. I, Pierre Rivière is most relevant to criminologists and historians of the French criminal justice system and the medical and psychiatric professions during the nineteenth century. At closer inspection, however, this book combines Foucault's earlier archaeological and later genealogical approaches ${ }^{9}$ to trace "truth games" encountered in a specific institutional nexus shaped by broader political and discursive forces.

Paul Brass subsequently developed Foucault's approach further. In Theft of an Idol, ${ }^{10}$ Brass subjects violent episodes recorded in Uttar Pradesh, India, to an analysis that takes its cue from I, Pierre Rivière. In each case examined (including rape and the theft of a religious idol), Brass demonstrates that "the facts at hand" were elusive. Adjusting the analytical vector, his intention is not to declare what happened or who the perpetrators of violence were; instead, Brass unpacks the political work performed through the claims made in the aftermath of violence. Brass's analysis uncovers that the interpretative struggles over the alleged, competing "truths" surrounding the incidents in question reveal the intentions of the enunciating speakers rather than the actual chronology of, or responsibility for, what happened. Various local actors, including politicians, had stakes in pushing specific interpretations in the absence of firm knowledge of the underlying facts. In a context of heightened communalism, the ensuing interpretative struggles allocated blame to a predefined "other," polarized populations along religious lines, and pursued electoral benefits from such boundary entrenchments. Geographically closer to the present article's empirical focus, Pieter Judson ${ }^{11}$ has made a similar argument. In relation to "village violence" in the late imperial period, Judson shows how nationalist preoccupations with drawing ethnolinguistic boundaries within heterogeneous populations came to frame local conflicts along the Habsburg Empire's "internal language frontiers" from the late nineteenth century onward.

Turning to our narrower context, the darkest chapters in Austrian history, World War II and the Holocaust, are famously well-researched, as are postwar continuities of antisemitic sentiments and exclusionary politics. ${ }^{12}$ Key themes in the well-covered terrain of Austria in the post-1945 era include the political opportunism of a quickly sedimented "victim myth,"13 which would be challenged by wider acceptance of "co-responsibility" the growing hegemony of a new identity narrative of "Austrian particularism" in juxtaposition to the pan-Germanic self-understandings that had dominated Austrian politics hitherto. ${ }^{15}$ The country's postwar challenges included the punishment of war criminals and the question as to how to deal with

\footnotetext{
${ }^{8}$ Michel Foucault, ed., Der Fall Rivière (Frankfurt, 1973).

${ }^{9}$ David Macey, The Lives of Michel Foucault (New York, 1995).

${ }^{10}$ Paul Brass, Theft of an Idol (Princeton, 1997).

${ }^{11}$ Pieter Judson, Guardians of the Nation: Activists on the Language Frontiers of Imperial Austria (Cambridge, MA, 2006), $177 \mathrm{ff}$.

${ }^{12}$ See, for example, Barbara Serloth, Von Opfern, Tätern und jenen dazwischen (Vienna, 2016).

${ }^{13}$ Ruth Wodak and Rudolf de Cillia, "Commemorating the past: The discursive construction of official narratives about the 'Rebirth of the Second Austrian Republic,"' Discourse \& Communication 1, no. 3 (2007): 315-41.

${ }^{14}$ Heidemarie Uhl, "From Victim Myth to Co-Responsibility Thesis," in The Politics of Memory in Postwar Europe, ed. Richard Ned Lebow, Wulf Kansteiner, and Claudio Fogu (Durham, 2006), 40-72.

${ }^{15}$ Peter Thaler, The Ambivalence of Identity (West Lafayette, 2001).
} 
more than 500,000 former Nazi Party members. Following steps toward "denazification" during the early postwar years, later amnesties were part of a for decades largely unproblematized reabsorption of former Nazis into the fabric of Austrian society. ${ }^{16}$ The two major political parties, the Social Democrats (SPÖ) and the People's Party (ÖVP), had a stake in speaking to all segments of society as part of their postwar politics of Proporz and consensual democracy. ${ }^{17}$ At the same time, parts of the "third camp," often compromised through previously closer ideological and organizational entanglements with Nazism, were soon reorganized: initially through the Verband der Unabhängigen and, as of 1956, through the FPÖ as its successor. ${ }^{18}$ While the (earlier) history of the FPÖ saw the party fluctuate between liberal and (pan-Germanic) nationalist fractions, Jörg Haider's rise to the party's apex in 1986 marked a definitive shift toward the (far) right. ${ }^{19}$ In the following decade and a half, against a backdrop of far-reaching shifts and changes in and beyond Austria, ${ }^{20}$ the FPÖ's election returns improved steadily, particularly though not only at the SPÖ's expense. ${ }^{21}$ Combining antiestablishment rhetoric with nationalist protectionism that opposed migration and multiculturalism, Haider found ever-growing audiences throughout the 1990s. The FPÖ's rise to power and international attention unfolded in the aftermath of the 1999 elections. The party's inclusion in a coalition with the ÖVP, under Wolfgang Schüssel, led to temporary "sanctions" put on Austria by her then fourteen EU partners and to vocal civil society opposition in Austria. ${ }^{22}$ The compromises required by its newfound position of power led to tensions internal to the FPÖ, and eventually to its splitting, in 2005, into the Haider-led Bündnis Zukunft Österreich ${ }^{23}$ and the "old" FPÖ, which was henceforth led by Heinz-Christian Strache. While Austria returned to successive grand coalition governments between the SPÖ and ÖVP, Strache moved the FPÖ further to the right, (re-)mobilizing growing segments of the electorate through campaigns that spanned EU-skepticism and Islamophobia. ${ }^{24}$ Against the backdrop of the "refugee crisis" of 2015/16, ${ }^{25}$ this strategy bore fruit at the 2017 national elections, leading to the ÖVP-FPÖ coalition government mentioned earlier.

The contexts thus set, the corpus of data to be examined in the following text needs to be outlined next. I draw on a main body of materials collected between the start of the Ibiza affair, marked by the publication of the video clip on the websites of the Süddeutsche Zeitung and Der Spiegel on 17 May 2019, and Strache's expulsion from the FPÖ on 13 December 2019. While the latter event constituted an undeniable milestone-and one that, in narrative-structural terms, contained elements of a classical fall from grace, as seen from Strache's emic perspective ${ }^{26}$-it did not mark the scandal's endpoint. As mentioned, the issues unearthed and follow-on scandals triggered by the Ibiza affair are a long way from being resolved, the "facts" by no means fully clarified. Investigations continue, as do the debates they have triggered. However, in the spirit of the Foucault-inspired genealogy of research summarized in the preceding text, the extensive materials collected between May and December 2019 offer insights into competing discursive-political positions that are (re)shaping Austrian political discussion today; some such positions long preexisted the scandal; others have been reconfigured in the course of it;

\footnotetext{
${ }^{16}$ Steven Beller, A Concise History of Austria (Cambridge, 2006), 258-59.

${ }^{17}$ Oliver Rathkolb, Die paradoxe Republik (Vienna, 2005), 365-404.

${ }^{18}$ Margit Reiter, Die Ehemaligen (Göttingen, 2019).

${ }^{19}$ See, for example, Hubert Sickinger, "Jörg Haider," in Kreisky-Haider: Bruchlinien österreichischer Identitäten, ed. Anton Pelinka, Hubert Sickinger, and Karin Stögner (Vienna, 2008), 111-220.

${ }^{20}$ Christian Karner, "National DOXA, Crises and Ideological Contestation in Contemporary Austria," Nationalism and Ethnic Politics 11, no. 2 (2005): 221-63.

${ }^{21}$ See Reinhold Gärtner, "The FPÖ, Foreigners, and Racism in the Haider Era," in The Haider Phenomenon in Austria, ed. Ruth Wodak and Anton Pelinka (New Brunswick, 2002), 28; Anton Pelinka, "The FPÖ in the European Context," in The Haider Phenomenon in Austria, 218.

${ }^{22}$ Allyson Fiddler, The Art of Resistance (New York, 2018).

${ }^{23}$ Haider died in a car crash in the outskirts of Klagenfurt in October 2008.

${ }^{24}$ See John Bunzl and Farid Hafez, eds., Islamophobie in Österreich (Innsbruck, 2009).

${ }^{25}$ Christian Karner, “Der Balkan' in der Krone: Austria between 'frontier Orientalism' and amnesiac nationalism," Interventions: International Journal of Postcolonial Studies, online first (2020), DOI: 10.1080/1369801X.2020.1718541.

${ }^{26}$ Johanna Hager, "Heinz-Christian Strache: Aufstieg und Fall des HC-Man," Kurier, 18 May 2019, https://kurier.at/politik/ inland/heinz-christian-strache-aufstieg-und-fall-des-hc-man/400498807.
} 
yet others amount to novel argumentative positions. Jointly, they reflect a shifting discursive-political field in a period of pronounced crises. The main data corpus was complemented by additional materials collected between the scandal's one-year "anniversary" in May 2020 and the early stages of the parliamentary inquiry that commenced the following month. Such additional data reflect further, still unfolding shifts in public debate surrounding the issues raised by "Ibiza." While emerging discursive positions and trajectories are highlighted in the following analysis, no end to the shifts triggered by the scandal is in sight. Instead, the events since May 2019 reveal, when viewed through the analytical framework applied here, the constitutive tensions of a political field in flux.

The sources systematically researched for coverage of the Ibiza affair throughout the period(s) in question spanned much of Austria's diverse field of media production. They included ideologically differently positioned quality dailies (Der Standard, Die Presse, Kurier), the weekly newsmagazine Profil, the Viennese left-leaning weekly Falter, the tabloid Österreich, and the country's most widely-ready paper and key protagonist in the fallout to the scandal, the Kronen Zeitung (or Krone), as well as coverage by Austria's public broadcasting network ORF. The rationale for casting my net widely was to capture diverse voices articulated across a range of media with diverse (intended) audiences and political leanings. Another key source was the account, published in book form ${ }^{27}$ in August 2019, by the two journalists who had been given access to the undercover recordings of Strache and Gudenus on $\mathrm{Ibiza}^{28}$ and who were the driving forces behind the revelations.

Before discussing these wide-ranging data ${ }^{29}$ my analytical strategy requires further commentary. In the spirit of the (post-)Foucauldian approaches outlined in the preceding text, this discussion probes data not for "what happened" but for what is being claimed and by whom; for which interpretations are being offered; and for the political trajectories and strategies enabled by the argumentative positions being adopted. These questions demand contextualization: understanding competing claims and interpretations on offer since May 2019 requires us to read them against the backdrop of the longer (Austrian) histories summarized earlier. What follows is structured thematically (rather than chronologically): the discussion unfolds around competing truth claims and argumentative positions that have shaped the discursive field that has opened up in Austria since May 2019. As in the (post-) Foucauldian lines of inquiry sketched earlier, the questions as to who speaks about an event and how take center space.

\section{Heinz-Christian Strache's Shifting Positions}

An analysis of the truth claims formulated in the fallout to the Ibiza scandal must start with the shifting positions adopted by its central protagonist. These can be contextualized in relation to Strache's EU election campaign prior to news of "Ibiza" breaking on 17 May 2019. Some three weeks earlier, Strache had lent his voice to the nationalist trope of a "population exchange" (Bevölkerungsaustausch), the conspiratorial claim that Austria is threatened by demographic shifts tied to migratory flows. ${ }^{30}$ Concurrently, Strache's electoral posters depicted him in statesman-like posture, promising to "protect what we love: Austria." ${ }^{31}$ This image and rhetoric were blatantly contradicted by the video revelations published soon thereafter. Strache's initial reactions appeared to show embarrassment, as conveyed-in front of international television cameras-during his resignation from all political offices and his apology to his supporters and wife. ${ }^{32}$

\footnotetext{
${ }^{27}$ Frederik Obermaier and Bastian Obermayer, Die Ibiza-Affäre (Cologne, 2019).

${ }^{28}$ The two investigative journalists were not the people behind-and hence responsible for-the recordings. On the contrary, Obermaier and Obermayer have consistently sought to protect their sources. Yet, this did not prevent the eventual arrests and investigations of several people presumed to be the organizers (Drahtzieher) of the 2017 recordings.

${ }^{29}$ All translations of sources in German are the author's.

${ }^{30}$ Die Presse, 28 Apr. 2019, https://www.diepresse.com/5619506/strache-spricht-von-bevolkerungsaustausch.

${ }^{31}$ Christian Karner, "National mythologies: theoretical reflections, empirical applications," Contemporary Austrian Studies 29 (2020): 21-42.

${ }^{32}$ Hager, "Heinz-Christian Strache"; Falter, 22 May 2019, p. 10. Obermaier and Obermayer describe Strache's resignation as characterized by a double strategy: Strache presented himself as regretful, but also as a victim of "criminal networks" staging a "political assassination attempt" (politisches Attentat); Die Ibiza-Affäre, 211.
} 
Partial regret soon gave way to outright counterattack as Strache's lawyers were reported to have filed complaints in Vienna, Munich, and Hamburg against the producers of the video. ${ }^{33}$ Declining to take up us his seat in the European parliament, which 45,000 preference votes would have enabled him to do, Strache announced in mid-June that for the time being he would be an "ordinary party member," that he was awaiting the results of the investigations into the "background to the Ibiza video," determined to fight for rehabilitation, and certain that his political life-"always focused on Vienna and Austria"-was "not over." ${ }^{34}$ Within days of his resignation, Strache had attemptedusing his enormously popular Facebook page, which still attracted some 800,000 fans after Ibizato shift attention toward the "initiators" of the video, who had "trapped" him in a purportedly "targeted attack against Austria's sovereignty." 35 As the scandal broadened and investigations were extended to also address suspicions of a possibly corrupt quid-pro-quo between the FPÖ and a gaming corporation, this led to police raids and the temporary confiscation of Strache's smartphone; Strache responded by calling this an "entirely arbitrary act" (reine Willkür) and "yet another political attack," while his lawyer filed a complaint against the raid and called for a stop to the proceedings. ${ }^{36}$ When soon thereafter German satirist Jan Böhmermann targeted, not for the first time, Strache in a televised political commentary, Strache's response made it clear whom he saw as the real danger: "Leftist hatred," Strache claimed on his new, private Facebook account (after the FPÖ had taken control of Strache's previous, much larger page), "goes to sickening lengths, this pseudo-satirist even wants to see me burn." ${ }^{37}$

Overall, Strache's recurring argumentative strategies have combined a belittling of what happened on Ibiza (in his words, this had been "merely" a b'soffene G'schicht, or alcohol-induced episodethough an admittedly embarrassing one) with denials of any responsibility, particularly through the claim, soon circulating among his most ardent supporters, that Strache had "not been himself," suggesting the conversations may have been brought about by drugs mixed into his drinks. The former strategy of (relative) trivialization appeared, for instance, in an interview with the editor of the daily tabloid Österreich in which Strach said-in apparent self-contradiction-that while he was genuinely sorry for having witnessed the destruction of his political work, he also believed that "forgiving oneself and others" was important and that he had a "clear conscience." 38 The second strategy emerged in claims, by both Gudenus and Strache, that they could not remember parts of the evening, leading them to speculate that they may have been drugged. ${ }^{39}$ In a joint interview with his wife, Strache also spoke of a "trap" allegedly set for him, including the "mixing of a substance" into his drinks, with Philippa Strache declaring that "this was not my husband, this was not alcohol." 40 This victimization topos and denial of responsibility stand in contrast to medical experts' assessments that found no evidence in Strache's and Gudenus's demeanor in Ibiza of any signs of "being drugged." 41 Commenting in another interview, on the fateful night and the subsequent police raid mentioned

\footnotetext{
${ }^{33}$ Anna Goldenberg, “Straches deutsche Strafanzeigen,” Falter, 12 June 2019, p. 23.

34"Strache nimmt EU-Mandat nicht an," ORF News, 17 June 2019, https://orf.at/stories/3127064/.

${ }^{35}$ Lukas Matzinger, "Von Ibiza zum Influencer," Falter, 5 June 2019, pp. 24-25. As Matzinger argues, this counterattack utilized a "now-more-than-ever-topos" (Jetzt erst recht). This trope references events of 1986, when it was employed by Kurt Waldheim's supporters in defiance of international calls for scrutiny of the then presidential candidate's-and subsequently elected federal president's-wartime past (Mitten, Antisemitic Prejudice, 4).

36“Strache bestätigt Hausdurchsuchung," ORF News, 13 Aug. 2019, https://orf.at/stories/3133621/; Kid Möchel and Dominik Schreiber, "Knalleffekt nach Razzia: Strache beantragt Einstellung des Verfahrens," Kurier, 27 Aug. 2019, https://kurier.at/politik/ inland/nach-handy-razzia-strache-beantragt-die-einstellung-des-verfahrens/400588943.

${ }^{37}$ Heute, "Jan Böhmermann will HC Strache 'brennen sehen,"” 1 Sept. 2019, https://www.heute.at/s/jan-bohmermann-will-hcstrache-brennen-sehen--40475457.

${ }^{38}$ Rosa Schmidt-Vierthaler, "Hochpeinliche Fragen an Strache: Das muss Ihnen doch wehtun,” Die Presse, 23 Aug. 2019 , https://www.diepresse.com/5678202/hochpeinliche-fragen-an-strache-das-muss-ihnen-doch-wehtun.

${ }^{39}$ Anna Thalhammer, "Heinz-Christian Strache will Ibiza-Video erwerben," Die Presse, 4 Nov. 2019, https://www.diepresse. com/5716507/heinz-christian-strache-will-ibiza-video-erwerben.

${ }^{40}$ Der Standard, "Ibiza: Strache sieht sich weiter als Opfer," 18 Sept. 2019, https://www.derstandard.at/story/2000108809792/ ibiza-strache-sieht-sich-weiter-als-opfer?ref=nl.

41"Gutachten: Strache stand auf Ibiza nicht unter Einfluss von K.-o.-Tropfen,” Der Standard, 26 Sept. 2019, https://www.derstandard.at/story/2000109116016/gutachten-strache-stand-auf-ibiza-nicht-unte-reinfluss-von-k.
} 
in the preceding text, Strache combined several argumentative positions: when the police arrived to raid his home, he said, he was "still naked," and professed to be "appalled and stunned" at this "act of injustice"; wondering why he had not been granted access to the full seven-hour Ibiza video recordings, Strache speculated that the journalists in question "might want to quote out of context" in onesided fashion; he again claimed to have seen himself "act in patterns I don't recognize," thus amplifying the drugging speculation; finally, Strache suggested that if there was no interest in a "genuine investigation" of the Ibiza video he may consider a political comeback. ${ }^{42}$

The conspiratorial tone of Strache's position culminated in his speech of 1 October, in which he announced that he would suspend his FPÖ membership. Portraying himself as a victim of "slander," "cowardly" employed by "our party's usual opponents," and his family as the "object of hatred" from which he sought protection, Strache spoke of hostilities that "endanger our democracy" and that-in contradiction to the earlier claim about "the usual opponents" - "still unknown forces had cultivated in criminal fashion for years." Strache appealed to party unity, lamenting that "such dirty methods for manipulating elections ... must not win out." 43

This statement had multiple intended audiences, including Strache's supporters and FPÖ colleagues. What the Foucauldian approach applied here enables is not a definitive pronouncing over the relative (in)accuracy of competing truth claims but a recording of the political positions they enable, of the shifting allegiances, oppositions, and self-presentations they transport, and the rhetorical-argumentative means they employ. The immediate question thus arises of the effectivity of Strache's calls for "party unity."

\section{The FPÖ: From Gradual Detachment to (Irrevocable?) Rupture}

A month prior to the most recent European elections and three weeks before the Ibiza revelations, comparative research suggested that among Europe's (far-)right-wing populists the FPÖ could rely on the largest share of committed voters (as opposed to fickle "protest voters"), namely some 14 percent of Austria's electorate. ${ }^{44}$ With the FPÖ polling 17.2 percent of the Austrian vote a month later, compared to 19.72 at the previous elections to the European parliament in 2014, this relative strength arguably still endured despite Ibiza. Yet, subsequent months were to test the FPÖ profoundly.

As observed in Austria's weekly newsmagazine Profil, ${ }^{45}$ the FPÖ's immediate strategy for handling the breaking scandal was to employ its proven tactics of conspiratorial "perpetrator-victim reversals," 46 threatening legal steps against purportedly "dirty methods"; yet the party soon realized that counterattack would prove ineffective given the scale of the revelations, and that resignations would be unavoidable. Attempts to deflect still continued. The video revelations had suggested that the FPÖ may have used a network of associations or think tanks to channel undeclared funds toward the party. At the end of May, the FPÖ, though it disbanded two such associations, bemoaned what it called a "media witch hunt" (mediale Hetzjagd) and declared that "no direct or indirect donations" had reached the party through those channels. ${ }^{47}$ In an interview published in Falter, Norbert Hofer-

\footnotetext{
42“'Strache: 'Man will mich politisch beschädigen,” Österreich, 18 Aug. 2019, pp. 4-5.

${ }^{43}$ Quoted in Der Standard, 1 Oct. 2019, https://derstandard.at/jetzt/livebericht/2000109290856/liveticker-strache-gibt-um1030-uhr-persoenliche-erklaerung-ab.

${ }^{44}$ Andreas Puschautz, "EU-Wahl: FPÖ kann auf größte Stammwählerschaft setzen,” Kurier, 27 Apr. 2019, https://kurier.at/ politik/eu-wahl/eu-wahl-fpoe-kann-auf-groesste-stammwaehlerschaft-setzen/400477609.

${ }^{45}$ Gernot Bauer, Eva Linsinger, Clemens Neuhold, Michael Nikbakhsh, Christina Pausackl, Christian Rainer, Robert Treichler, Jakob Winter, and Christa Zöchling, "Russische Eier," Profil, 19 May 2019, pp. 12-16.

${ }^{46}$ Ruth Wodak, Politik mit der Angst (Vienna, 2016), 20; see also "Die FPÖ und die Macht der Bilder," ORF News, 22 May 2019, https://orf.at/stories/3124078/.

47“FPÖ wehrt sich gegen Vorwürfe zu Vereinen,” ORF News, 25 May 2019, https://orf.at/stories/3124316/. Ongoing investigations have suggested otherwise, reporting that hundreds of thousands of euros may indeed have been donated by industrialists to associations with ideological and personal connections to the FPÖ: see "Bericht: Großspenden von Industriellen an FPÖ-nahe Vereine," ORF News https://www.orf.at/stories/3154929/; see also Renate Graber, "Wieder Razzien bei Novomatic, FPÖ-nahe Vereine im Visier," Der Standard, 11 Mar. 2020, https://www.derstandard.at/story/2000115614258/wieder-razzien-bei-novomatic-weg.
} 
Strache's successor at the FPÖ's helm-was then still ambivalently semiprotective of his predecessor, explaining why Strache had not (yet) been expelled from the FPÖ. Hofer argued that the potential quid-pro-quos discussed by Strache, as recorded in the Ibiza video, had not taken place; and although the party was "concerned," Hofer repeated Strache's defensive account that he was "not like this" and that "something may have been mixed into his drink." Further, Hofer argued that Strache had not been expelled because this would have "torn the party apart" and because of Strache's "lifetime achievements" for the FPÖ. ${ }^{48}$ When, in late August, the scope of the investigations ${ }^{49}$ was narrowed, as suspicions of bribery seemed not to have been substantiated at this point, FPÖ general secretary Harald Vilimsky considered Strache and Gudenus to be at least partly "exonerated." 50

Concurrently, the FPÖ's tone about Strache was shifting. By July, Strache and the FPÖ were arguing over control of Strache's Facebook page, leading Hofer to claim that the importance of the latter was "completely overestimated." The subsequent suspicions over possible corruption implicating Strache, some of his colleagues, and a high-profile appointment for the international gambling company Novomatic were recognized as posing yet more "explosive" questions for the FPÖ. ${ }^{52}$ With Austria's snap elections approaching, the situation was exacerbated by allegations against Strache, involving a former secretary and bodyguard, of financial misspendings. ${ }^{53}$ Yet, on the eve of Austria's parliamentary elections, Norbert Hofer posted a Facebook video in which he rhetorically tied the "Ibiza trap" (set by "criminal organizations") to the more recent timing of revelations of Strache's alleged financial improprieties, postulating a "political attack against Austrian democracy." ${ }^{\prime 4}$ On 29 September, the political price of preceding events became apparent to the FPÖ, as the party's share of the vote-at 16.17 percent-constituted a decrease of almost 10 percent compared to the 2017 elections.

Eventually, a rupture between Strache and his former colleagues in the party he had led for fourteen years became inevitable. As the months following the initial publication of the Ibiza reports unfolded, one scandal had become many. Henceforth, the FPÖ's tactical focus would be to draw a clear boundary between itself and its former head. Therein lies one of this article's central insights: the Foucauldian approach captures the (re)drawing of political boundaries-accomplished by publicly articulated and circulated claims and interpretations pertaining to the scandal in question- "in action," so to speak. In relation to the FPÖ's emerging repositioning vis-à-vis Strache, this was already apparent prior to the snap elections: internal party voices acknowledged that allegations of Strache invoicing the party for personal expenses contradicted the image the FPÖ had cultivated, making a "comeback" by Strache "well-nigh impossible." ${ }^{55}$ On 1 October 2019, the FPÖ suspended Strache's party membership. Two months, further allegations of possible financial improprieties by Strache, ${ }^{56}$ and the defection of three Viennese FPÖ councillors (and Strache supporters) and their founding of a new electoral platform (Die Allianz für Österreich, DAÖ) later, Strache was expelled from the FPÖ on 13 December 2019. Preceding weeks had seen growing acrimony between Strache and his former colleagues, some

\footnotetext{
48“"Ein Ausschluss Straches hätte die FPÖ zerrissen," Falter, 26 June 2019, pp. 16-17.

${ }^{49}$ The Public Prosecutor's Office against Corruption has investigated a range of suspicions focused on Strache, Gudenus, and FPÖ MP Markus Tschank arising from the conversations recorded in the Ibiza video. See Joseph Gepp and Jakob Winter, "Die dreisten Drei," Profil, 16 June 2019, pp. 14-16.

50“Justiz verzichtet auf einzelne Ermittlungen," ORF News, 29 Aug. 2019, https://orf.at/stories/3135365/.

51“Hofer zu Straches Facebook-Seite: 'Völlig überschätzt,"” Der Standard, 1 July 2019, https://www.derstandard.at/story/ 2000105613266/hofer-zu-straches-facebook-seite-oh.

${ }^{52}$ Andreas Schnauder, "Die Casinos-Affäre hat für die FPÖ noch mehr Sprengkraft als Ibiza," Der Standard, 14 Aug. 2019, https:// www.derstandard.at/story/2000107402613/die-casinos-affäre-hat-fuer-die-fpoe-noch-mehr-sprengkraft?ref=nl.

53“Staatsanwaltschaft ermittelt wegen Untreueverdachts," Der Standard, 26 Sept. 2019, https://www.derstandard.at/story/ 2000109111660/staatsanwaltschaft-ermittelt-wegen-untreueverdacht-gegen-strache; "FPÖ schließt Straches Ex-Bodyguard aus," ORF News, https://orf.at/stories/3138369.

54“Hofer: 'Ein Anschlag auf die Demokratie,"” OE24, 26 Sept. 2019, https://www.oe24.at/wahl2019/fpoe/Hofer-ueber-StrachesLeibwaechter-Ein-Anschlag-auf-die-Demokratie/398875575.

55“Spesenaffäre sorgt für Brodeln in FPÖ," ORF News, 26 Sept. 2019, https://orf.at/stories/3138589/.

56"Fotos von Tasche mit Bargeld in Straches Ermittlungsakt," Der Standard, 4 Dec. 2019, https://www.derstandard.at/story/ 2000111861009/fotos-von-tasche-mit-bargeld-in-str.
} 
due to Strache's anger at the FPÖ's having taken control of "his" former Facebook page. ${ }^{57}$ Two weeks prior to Strache's expulsion, former interior minister (and now party whip) Herbert Kickl declared that "there was no room in the FPÖ anymore" for Strache. ${ }^{58}$ With the party seeking to distance itself from all that had happened, the FPÖ's new leadership presented Strache's expulsion as a "liberation" and a "line drawn" (Schlussstrich) after the "Ibiza affair."

Subsequently, following Strache's appearance at a gathering of the newly founded DAÖ, which was later renamed "Team HC Strache-Allianz für Österreich" and had become (under Strache's leadership) the FPÖ's direct competitor in Vienna, the FPÖ reacted with dismay. Dominik Nepp, head of the Viennese FPÖ branch, criticized Strache for having “mocked” local functionaries' long-standing commitment; Nepp suggested that Strache was egocentric, self-pitying, incapable of admitting mistakes, and perhaps constructing a "parallel world" detached from reality. ${ }^{60}$ A similar, pseudo-psychiatric discourse of discrediting through the rhetorical use of diagnostic labels surfaced soon thereafter. The FPÖ's electoral trouncing in Burgenland's regional elections led to a blame game between Strache and his successor using Twitter. After Strache had interpreted the Burgenland results as suggesting that Hofer was making the party "irrelevant," Hofer replied with a tweet showing an unflattering image of Strache taken from the "Ibiza video" and an ironic "thank you." The following day, the regional head of the FPÖ's Tyrolean branch tweeted this "advice" for Strache: "Having partly caused a state crisis [and] lived at the party's expense ... [he] blames others. No sign of regret.... The only things that may help are a psychiatrist or an exorcist." 61

The Ibiza scandal has implicated a wide range of actors. Turning to another (set of) player(s) in the affair, the tabloid Kronen Zeitung, Paul Brass's ${ }^{62}$ focus on "competing frameworks of meaning" in the struggle over politically charged episodes bears repeating: each (re)construction constitutes an "artifact" with a distinctive "life" and "the most useful function the social scientist can perform ... is to identify the uses to which a construction is put and the power relations ... expressed through it."

\section{The Kronen Zeitung: Ideological Realignment?}

Austria's most popular newspaper found itself a central topic in the undercover recordings of Strache's and Gudenus's conversations with the purported oligarch's niece on Ibiza. The book-length account by the investigative journalists from the Süddeutsche Zeitung whose reporting on the video was key to the revelations contains the following passages related to the Kronen Zeitung:

[T] he conversation moves to what Johann Gudenus calls the "main topic": the Kronen Zeitung.... The woman whom the two FPÖ-politicians know as Aljona Makarowa allegedly wants to buy half the tabloid ... and align it with the FPÖ.... Strache is electrified: the Krone is Europe's "most powerful paper proportional to population size." ... "Importantly," Strache explains, "we have friendly access ... to the shares held by the Funke-group." ... Strache suggests that if the Russian bought the 50 percent held by [the heirs of the paper's founder] Dichand, schwupp, "then you have it all." ... The Russian's chaperone chimes in: the paper's journalists would be divided into those already in line, ... those who can be brought in line ... and others to be sidelined. Strache nods, "journalists are the planet's biggest prostitutes anyway." ... "Once she takes over the Kronen Zeitung ... we must sit down [zusammenhocken] and talk ... zack, zack, zack," he would "push" three or four people, bring in five new ones, three or four others "would go" [abserviert werden]. ${ }^{63}$

\footnotetext{
57“Streit um Facebook-Seite: Strache wütet gegen die FPÖ,” Der Standard, 17 Oct. 2019, https://www.derstandard.at/story/ 2000110003767/strache-wuetet-gegen-die-fpoe-1848er-freiheit-statt-ddr-zensur.

58“Kickl will Strache lieber heute als morgen loswerden," Der Standard, 30 Nov. 2019, https://www.derstandard.at/story/ 2000111712612/kickl-will-strache-lieber-heute-als.

59“Strache aus FPÖ ausgeschlossen," ORF News, 13 Dec. 2019, https://orf.at/stories/3147497/.

60"FPÖ sieht 'Verhöhnung' durch Strache," ORF Wien, 24 Jan. 2020, https://wien.orf.at/stories/3031376/.

61"Abwerzger geht mit Strache hart ins Gericht," ORF Tirol, 27 Jan. 2020, https://tirol.orf.at/stories/3031922.

${ }^{62}$ Brass, Theft of an Idol, 61.

${ }^{63}$ Obermaier and Obermayer, Die Ibiza-Affäre, 57-64.
} 
This requires context. The partial ideological overlaps between the Krone and Austria's New Right have frequently been commented upon. Ruth Wodak ${ }^{64}$ argues that the paper had already "celebrated" the FPÖ's electoral performance four days before the controversial elections of 1999, which would see the party's share of the vote increase to 26.9 percent. Pointing at areas of convergence (i.e., an antiimmigration stance, the neoliberal paradigm, the critique of political elites), Michael Rittberger ${ }^{65}$ has argued that Jörg Haider's success would have been "hard to imagine" without the Kronen Zeitung's (implicit) endorsements. Yet, notwithstanding the paper's consistent leanings toward a populism skeptical of European integration and dismissive of the benefits of migratory flows or of the likelihood of a mutually enriching multiculture, it is misleading to reduce the Krone to an unfaltering or singular ideological position: its pages, positions, and much-discussed readers' letters also contain occasional shifts or examples of "counter-discourse." 66

This raises the question as to how the Kronen Zeitung, a core focus of Strache's attention in his will to power, responded to such fantasies of a "takeover." While a full exploration, including of readers' responses to Ibiza in letters to the editor, exceeds the scope of this article, an indication of the Krone's responses to the scandal can be gleaned from its acting editor-in-chiefs daily commentary on current affairs. Arguably, (growing) ambivalence toward the FPÖ was already discernible on 24 April 2019, when Klaus Herrmann questioned-in light of a xenophobic outburst by an FPÖ deputy mayor from Upper Austria-whether the party was a suitable coalition partner. The day after the scandal broke, the paper's headline declared that the FPÖ was "finished" (FPÖ am Ende!), expressing outrage at the reported plans to "buy" the paper and calling for Strache's and Gudenus's resignations. ${ }^{67}$ The following day, Herrmann described Strache's "political suicide" and the scandal as Austria's "topic of the decade." 8 One week on, the paper's front page declared that those were "fateful days for Austria," with the editor-inchief reflecting on how Strache had wanted to "Orbanize" Austria's media; in an ironic, intertextual reference to Strache's most infamous Ibiza statement, this-so typical of Herrmann-had "zack, zack, zack led to Strache's demise." ${ }^{69}$ Neither have critical comments been restricted to Strache. Instead, several episodes saw the editor's criticisms extended to the FPÖ, thereby refusing the party's strategy of splitting (i.e., Strache's expulsion) documented in the preceding section. Thus, Herrmann variously amplified calls for the FPÖ to disclose its financing strategies, ${ }^{70}$ echoed suspicions of connections between the FPÖ and the far-right, radical Identitären, ${ }^{71}$ and expressed incredulity after FPÖ politician Ursula Stenzel had spoken at a rally organized by the Identitären-only for the party to claim that Stenzel had not been "fully aware" whom she had addressed. ${ }^{72}$ Similarly, Herrmann supported those expressing grave concern at the second reported scandal-in less than two years-triggered by an FPÖ functionary's membership in a fraternity shown to possess songbooks with antisemitic content. ${ }^{73}$

The Kronen Zeitung's unsurprising offense at Strache's ideas recorded in the Ibiza video need not necessarily lead to an enduring ideological realignment on the part of the paper. Some commentators have observed that the Krone has recently turned toward environmental issues and that, through a satirical tweet in the aftermath of the FPÖ's trouncing in September, the paper seemingly claimed some influence on the election results. ${ }^{74}$ Others have doubted the Krone's claims not to be the kind of tabloid Strache had planned to instrumentalize for electoral gain but an "independent family

\footnotetext{
${ }^{64}$ Wodak, Politik mit der Angst, 198.

${ }^{65}$ Michael Rittberger, "Wie kommt die Ausländerfeindlichkeit in die Kronen Zeitung?," in Dazugehören oder nicht?, ed. Sevgi Bardakçi et al. (Innsbruck, 2009), 50-52.

${ }^{66}$ Christian Karner, "The Uses of the Past and European Integration: Austria between Lisbon, Ireland, and EURO 08," Identities 17, no. 4 (2010): 402.

${ }^{67}$ Kronen Zeitung, 18 May 2019, p. 1.

${ }^{68}$ Kronen Zeitung, 19 May 2019, p. 6.

${ }^{69}$ Kronen Zeitung, 26 May 2019, pp. 1, 6.

${ }^{70}$ Kronen Zeitung, 5 June 2019, p. 6.

${ }^{71}$ Kronen Zeitung, 2 Aug. 2019, p. 6.

${ }^{72}$ Kronen Zeitung, 9 Sept. 2019, pp. 1, 6.

${ }^{73}$ Kronen Zeitung, 31 Oct. 2019, p. 6.

74“Krone twitterte Erinnerung an Straches Ibiza-Wahlprognose: 'Sorry' an FPÖ,” Der Standard, 30 Sept. 2019, https://www. derstandard.at/story/2000109268183/krone-twitterte-erinnerung-an-strac.
} 
newspaper."75 It was thus stressed that shortly before "Ibiza" the Krone had still endorsed the FPÖ's calls for a scrapping of public broadcasting fees. ${ }^{76}$ Others, most notably the Falter's editor, have been more skeptical, arguing that Strache's view of the Krone as key to power was worryingly accurate, and predicting that "reactionary resentments" would continue to feature in the Kronen Zeitung. ${ }^{77}$

As with much of "Ibiza," a final word on the scandal's long-term impact on the Krone's positioning cannot yet be spoken. While it is too soon to assess the extent or durability of any potential distancing from positions the paper has historically shared with the FPÖ, it is the case that prominent voices in the latter have bemoaned what they have presented as a shift in the paper's editorial steer since "Ibiza." In November 2019, the FPÖ's general secretary Christian Hafenecker published an open letter in which he announced that he had cancelled his subscription to the Kronen Zeitung. This, Hafenecker argued, was due to the paper's "unparalleled campaign" against the FPÖ, despite his party's alleged accomplishments in "seventeen months of government responsibility"; the Krone's new editorial tone, Hafenecker continued, departed from the "objectivity," "independence," and "balance" that had underpinned the paper's success over the preceding sixty years. ${ }^{78}$

Elaborating on I, Pierre Rivière, Paul Brass ${ }^{79}$ postulates that the examination of uneasily coexisting but mutually "interpenetrating" interpretations can enable a sharper view of "competing discourses, systems of thought, and relations of domination." This becomes clear as we turn to interpretations of Ibiza offered by the FPÖ's former coalition partner and now political competitor.

\section{The ÖVP: Controlled (and Contested) Distancing}

Turning to the next group of protagonists' voices in this drawn-out (set of) scandal(s), we encounter more evidence of how various "frameworks of meaning" have been employed in a context that has provided different actors with "opportunities to make use of [select] incidents for wider political purposes." ${ }^{\prime 80}$ For the ÖVP, the dominant partner in a coalition government with the FPÖ at the time the Ibiza scandal broke, the affair has provided a similar need-and simultaneously possibilities-to redefine itself and its positions vis-à-vis political competitors. The range of the ÖVP's argumentative stances, especially when faced with speculations that its potential entanglements ${ }^{81}$ might have gone beyond those of being a coalition partner to the FPÖ, constitute discursive terrain that exceeds the scope of the present article; a comprehensive discussion will have to await future analyses and requires more clarity than we have at present as to the details behind the affair. All that can be offered here is a schematic tracing of key positions adopted by the ÖVP in the aftermath of the revelations.

A day after the initial publications, on 18 May 2019, Chancellor Sebastian Kurz's statement and call for snap elections were noteworthy for being simultaneously backward and forward looking:

"Two years ago, I stepped up to accomplish change in our country. I also promised to articulate uncomfortable truths." He says in recent months he had to put up with a lot [i.e., scandalous statements by individual FPÖ politicians], yet he pushed through. "But after yesterday's video, I have to say,... enough is enough." Hence, new elections were needed now, and he would like to ask Austrians for their support because "only if the ÖVP is dominant after the elections, can we continue and complete those changes." 82

\footnotetext{
${ }^{75}$ Quoted in Barbara Tóth, "Im Blindflug," Falter, 3 July 2019, p. 24.

${ }^{76}$ Thomas Hoisl and Clemens Neuhold, "Die neue Krone und das alte Österreich," Profil, 22 Sept. 2019, pp. 35-36.

${ }^{77}$ Armin Thurnher, "Alte Krone/ Neue Krone - aus 60 Jahren Finsternis durch Ibiza ans Licht," Falter, 3 July 2019, p. 5; Armin Thurnher, "Die neue Krone ist die alte Krone, oder sie ist es nicht mehr," Falter, 17 Sept. 2019, p. 5.

${ }^{78}$ Quoted in “Ibiza-Nachwehen: FPÖ beklagt in offenem Brief den Kurs der 'Krone,"” Der Standard, https://www.derstandard. at/story/2000110701839/ibiza-nachwehen-fpoe-beklagt-in-offenem-brief-den-kurs-der?ref=nl.

${ }^{79}$ Brass, Theft of an Idol, 59.

${ }^{80}$ Ibid., 96.

${ }^{81} \mathrm{~A}$ suspected entanglement revolved around the Casino-Affäre, the alleged quid pro quo between, primarily, the FPÖ and the gaming corporation Novomatic. See Christina Hiptmayr, Stefan Melichar, and Michael Nikbakhsh, "Gibt es für die FPÖ einen Job in der Casag," Profil, 19 Jan. 2020, pp. 28-33.

${ }^{82}$ Nina Horaczek and Barbara Tóth, "Ein Kanzler macht Schluss," Falter, 22 May 2019, p. 16.
} 
This contained several topoi-an argument's implicit premises-and patterns of "positive self-presentation and negative other-presentation" 83 that have been part of the ÖVP's positions since Ibiza. The party's central argument has included a justificatory strategy with regard to its initial decision to enter into a coalition with the FPÖ, coupled to the ÖVP's self-portrayal as a party of integrity in the current crisis. This was the argumentative logic behind Sebastian Kurz's decision to ask for interior minister Herbert Kickl's resignation very soon after the scandal broke, for Kickl had been the FPÖ's general secretary at the time of the undercover recordings, an entanglement at odds with responsibility for overseeing investigations into potentially undeclared party financing for the FPÖ. Emphasizing that he was still " 100 percent behind" the coalition's political foci, Chancellor Kurz also insisted that the FPÖ had not realized "the full scale" of the scandal. ${ }^{84}$ After the parliament's vote of no confidence on 27 May, Kurz ${ }^{85}$ again expressed his satisfaction with the now-collapsed coalition's previous accomplishments, coupled with doubt as to whether a renewed collaboration with the FPÖ would be possible (i.e., Kurz contrasted Hofer to Kickl, suggesting that they represented different reactions to Ibiza within the FPÖ and arguing that "time would tell" which strand would shape the FPÖ going forward). Concurrently, reflecting the ÖVP's general strategic (re)positioning, Kurz saw barely any productive connections (kaum Anknüpfungspunkte) with the Social Democrats, thus making a return to Austria's long tradition of grand coalitions seem highly unlikely. ${ }^{86}$ A binary logic contrasting other parties' reactions to Ibiza to that of the ÖVP featured in the latter's general response to the vote of no confidence: ÖVP whip August Wöginger described his party as conscious of its responsibilities, whereas the SPÖ had acted "against the people and the Federal President's will" by throwing the country-in collaboration with the FPÖ_- "into chaos." ${ }^{87}$ Similarly, Kurz detected "vengefulness" in other parties, describing the no confidence vote against his short-lived, post-Ibiza cabinet as "incomprehensible to everyone in the country," while reasserting the ÖVP's commitment to stability and emphasizing that all financial donations to it had been entirely legal. ${ }^{88}$

Other positions adopted by Kurz and the ÖVP have included: advice directed at Strache "not to return" to politics; ${ }^{89}$ closer to the elections, an ever-clearer distancing from the former coalition partner, with the ÖVP's Gernot Blümel declaring that Strache and Kickl were claiming a "victim role" instead of aiding the Ibiza investigations; ${ }^{90}$ and criticism of purported connections between individual FPÖ functionaries and the far-right extremist Identitären..$^{91}$ Putting clear blue water between oneself and the FPÖ had become even more important for the ÖVP in light of a widening of the investigations into potentially hidden financial donations, with the question being posed as to whether not only the FPÖ but also ÖVP and SPÖ may have indirectly benefitted from some such undeclared financial flows. ${ }^{92}$ Meanwhile, reports that a previous employee of the chancellor's office had secretly had five hard drives disposed of shortly after the start of the Ibiza affair ${ }^{93}$ led to speculations that the ÖVP may have already known about the Ibiza video before its publication in Süddeutsche Zeitung and

\footnotetext{
${ }^{83}$ Krzyżanowski and Wodak, The Politics of Exclusion, 22-23

84"Damoklesschwert über Kurz," ORF News, https://orf.at/stories/3123490/.

85 "Kurz verteidigt Vorgehen erneut," ORF News, https://orf.at/stories/3124940/.

${ }^{86}$ There were acrimonious exchanges between ÖVP and SPÖ following Kurz's speculation that the SPÖ—or its former international consultant Tal Silberstein, who had fabricated misinformation and used "dirty campaigning" against Kurz in 2017-may have been behind the "Ibiza video" (ibid.). A Viennese court subsequently issued an injunction against such speculation (Kleine Zeitung, 28 Aug. 2019, https://www.kleinezeitung.at/politik/innenpolitik/5680833/IbizaVideo_OLG-bestaetigte-einstweiligeVerfuegung-gegen-Kurz).

87“Aus für Regierung Kurz,” ORF News, https://orf.at/stories/3124711/.

${ }^{88}$ In the Ibiza recordings, Strache appeared to suggest that undeclared financial donations were a strategy from which other parties, including the ÖVP, were also benefitting.

89“"Kurz: 'Ich würde ihm nicht raten zurückzukehren,"' Kronen Zeitung, 23 June 2019, https://www.krone.at/1946391.

90“'Blümel geht auf Distanz zu Türkis-Blau," ORF Wien, 25 Aug. 2019, https://wien.orf.at/stories/3009961/.

91“ÖVP-FPÖ-Zwist um Kickls Kabinettschef," ORF News, 22 Sept. 2019, https://orf.at/stories/3138108.

92“ Ö̈sterreichs Ibiza-Affäre weitet sich aus," Süddeutsche Zeitung, 9 July 2019, https://www.sueddeutsche.de/politik/stracheibiza-video-parteispenden-ermittlungen-1.4518076.

${ }^{93}$ Falter, 24 July 2019, pp. 1, $16 f$.
} 
Der Spiegel ${ }^{94}$ this was categorically denied by the ÖVP, with Sebastian Kurz stressing that disposing of data was part of any government handover. ${ }^{95}$ Finally, ÖVP allegations, first made in June, that someone had illegally accessed the party's computer frame and fabricated fake internal emails making false claims about the genesis of the Ibiza video were seemingly substantiated when a suspect was identified and prosecuted in relation to this. ${ }^{96}$ Less than a month before the snap elections, the ÖVP also reported a major hacking of its internal communications, accompanied by theft and subsequent manipulation of the stolen data, presumably intended to enable the circulation of false, discrediting information about the party. ${ }^{97}$

The ÖVP's attempts to distance itself from what the Ibiza revelations had brought to light about its former coalition partner have been countered by political and journalistic voices suspecting that compromising entanglements (e.g., in relation to the Novomatic issue) may have cut across the FPÖ-ÖVP divide. This has become pronounced in the context of the current (June 2020) parliamentary inquiry. Prior to its start, SPÖ politician Jörg Leichtfried had called it an elucidation of-staggeringly, in this order-an "ÖVP-FPÖ scandal" (türkis-blauer Skandal). ${ }^{98}$ The FPÖ, meanwhile, now approaches the issue through a relativizing and deflecting topos, the implicit, connotative subtext of which claims that others (i.e., the ÖVP) are getting away with matters for which allegedly only the FPÖ is being (wrongly) victimized. Before the inquiry's start, Herbert Kickl predicted that this would reveal nepotistic networks and financial channels far beyond the FPÖ. ${ }^{99}$ Since then, the FPÖ's attempts to whitewash itself and to shift attention toward what it portrays as a system skewed by its former coalition partner have centered on accusations that the ÖVP may obstruct parts of the Ibiza investigations and was even-the FPÖ here uses the conspiratorial "deep state" trope-creating a "state within the state." 100

Concurrently, other suggestions that the ripple effects of "Ibiza" go beyond the FPÖ also feature elsewhere. Commenting from a very different position and taking stock of months of investigations into the full range of suspicions and allegations, Falter's Florian Klenk has notably spoken of a political "morass" that implicates not only the FPÖ but also the ÖVP (türkise Sümpfe). ${ }^{101}$ In short, Ibiza-related attention has been partly (re)directed toward the ÖVP. This and the latter's responses again underscore conflicting forms of political boundary-work brought about by the scandal. The ÖVP has consistently claimed clear distance from its former coalition partner. The FPÖ and, in less apparently self-interested fashion, the rest of the current parliamentary opposition and parts of Austria's broadsheet press, meanwhile, have asked questions that blur or reject such purportedly clear distinctions and that are tantamount to a possible extension of responsibility beyond the FPÖ for the wider issues unearthed through Ibizagate. ${ }^{102}$

In the cacophony of voices, statements, and speculations about the Ibiza affair and its aftermath, important space has thus also been claimed by diverse positions critical of the political status quo and of the contradictions and structural issues that have surfaced through the scandal.

\footnotetext{
${ }^{94}$ E.g., "Hat ÖVP Ibiza-Video schreddern lassen?" Heute, 15 Aug. 2019, https://www.heute.at/s/hat-ovp-ibiza-video-schreddern-lassen--50778356.

95“Fünf Festplatten wurden geschreddert," ORF News, 23 July 2019, https://orf.at/stories/3131233/.

96“'Ominöse 'Ibiza-Mails," ORF News, 2 Oct. 2019, https://orf.at/stories/3139546/.

97“Nächste Datenaffäre mit offenen Fragen,” ORF News, 5 Sept. 2019, https://orf.at/stories/3136215/.

98“"Ibiza'-Ausschuss: SPÖ legt bei Kritik an Austragungsort nach," ORF News, 21 May 2020, https://orf.at/stories/3166578/. 99“'SPÖ and NEOS stellten Ladungsliste vor," ORF News, 12 May 2020, https://orf.at/stories/3165365/.

100“"Ibiza'-Ermittlungen: FPÖ empört über 'Schattenaffäre,"” ORF News, 10 June 2020, https://orf.at/stories/3169063; “'IbizaVideo': Gudenus-Fotos bei mutmaßlichem Drogenkonsum," ORF News, 16 June 2020, https://orf.at/stories/3169814/.

${ }^{101}$ Florian Klenk, "Die Sümpfe von Ibiza," Falter, 15 May 2020, pp. 20-22.

${ }^{102}$ The parliamentary inquiry's questioning of Chancellor Kurz on 24 June 2020 reflected this: the opposition queried potential ÖVP entanglements in the Novomatic issue and party financing. Kurz again sought to clearly separate his and the ÖVP's doings from the FPÖ's. See "Viel Ärger und zähe Geplänkel," ORF News, 24 June 2020, https://orf.at/stories/3170858/. Marking the endpoint of my data collection only, it is clear that Kurz's responses to the inquiry will not end discussion of the issues in question.
} 


\section{Critical Voices}

Full analysis of the entire range of voices critical of the former ÖVP-FPÖ coalition throughout the unfolding of the scandals triggered by the Ibiza revelations exceeds the scope of the present article. Anticipating more work on this facet of the discursive-argumentative fault lines that have deepened since May 2019, all that can be offered here is a sketch of prominent positions and "genres" of criticism. Those have spanned journalistic insistence on investigating the structural and cultural conditions of possibility underpinning everything that has come to light since the Ibiza revelations; calls-by parts of the political opposition, for instance-for legislative changes pertaining to party finances; and, at least temporarily, a wider, though certainly not uncontested, ${ }^{103}$ registering that Ibiza had discredited the politics claimed by Heinz-Christian Strache.

The arguably most obvious, and a much-repeated, criticism in the aftermath of the initial Ibiza revelations was that Strache's videotaped intentions flagrantly contradicted some of his long-professed positions. Given long-standing anxieties about the possible commodification of Austrian water and the FPÖ's opposition to any such developments, ${ }^{104}$ Strache's suddenly diverging thoughts recorded on Ibiza are worth quoting:

"The water business can only be managed in such a way that we, as the state, take our white gold into the state-owned domain, and then hire someone who manages this in the private sector." And there the Russian could enter the equation. ${ }^{105}$

Der Standard, ${ }^{106}$ for one, was quick to show that whatever the details of Strache's contemplations, they flew in the face of the FPÖ's programmatic stance against any privatization of water, which Strache had asserted consistently since 2007 .

As the scandal unfolded into a succession of interconnected scandals, critical journalistic voices had much to comment on: some questioned the parliament's vote of no confidence at the very moment Sebastian Kurz had apparently learned that a coalition with the far right was impossible; ${ }^{107}$ others - rejecting Strache's and the FPÖ's attempts to deflect and portray themselves as "victims of an intrigue"-thanked the investigative journalists at Der Spiegel and Süddeutsche Zeitung for revealing an "attack on democracy" and a "betrayal of Austrian citizens." 108 Obermaier and Obermayer, when interviewed in Profil, ${ }^{109}$ amplified voices rejecting Strache's attempts to belittle the scandal by reasserting that he and Gudenus had repeatedly brought up the topic of the Kronen Zeitung; that Strache had needed no prompting to discuss possible government contracts for the purported oligarch's niece; and that the latter's assumed wealth had been the main topic of discussion. Some cautioned voters against falling for the FPÖ's later strategy (à la René Girard) of reclaiming the party's self-ascribed integrity by scapegoating Strache only. ${ }^{110}$ Yet others warned against any splitting strategies-following the federal president's declaration that Austrians were not as depicted by two of the country's politicians in the Ibiza video-that effectively projected deep-seated issues exclusively onto Strache and Gudenus. Chauvinistic machismo, it was argued, recurred across the spectrum, as did a susceptibility to potential corruption. Further, Strache had been recorded describing undeclared financial flows benefitting political parties, against which Austria's transparency activists had warned for years. ${ }^{111}$ In the immediate aftermath of Ibizagate, the country's smaller parties Jetzt, NEOS, and the Greens had already asked

\footnotetext{
${ }^{103}$ Public debate since Ibiza has certainly not adopted a homogeneous line on the scandal. This corroborates that crisis periods transform taken-for-granted domains of cultural common sense (doxa) into internally contested fields of competing political positions: Pierre Bourdieu, Outline of a Theory of Practice (Cambridge, 1977), $167 \mathrm{ff}$.

${ }^{104}$ Christian Karner, “The Market and the Nation: Austrian (Dis)agreements," Social Identities 14, no. 2 (2008): $161-87$.

${ }^{105}$ Obermaier and Obermayer, Die Ibiza-Affäre, 88.

106““Kein Spekulationsobjekt’: Strache wollte Trinkwasser 2013 noch schützen,” Der Standard, 20 May 2019, https://derstandard.at/2000103489586/Kein-Spekulationsobjekt-Strache-wollte-Trink.

${ }^{107}$ Michael Lingens, "Es braucht Schutz vor Rechtsextremen," Falter, 29 May 2019, p. 8.

${ }^{108}$ Philippe Narval, "Die FPÖ, ein Opfer? Es reicht!” Der Standard, 28 May 2019, https://mobil.derstandard.at/ 2000103916749/Die-FPOe-ein-Opfer-Es-reicht.

${ }^{109}$ Profil, 18 Aug. 2019, p. 17.

${ }^{110}$ Isolde Charim, "Straches neue Rolle: der Sündenbock," Falter, 3 Dec. 2019, p. 9.

${ }^{111}$ Nina Brnada, "Der Strache in dir,” Falter, 5 June 2019, p. 6.
} 
for a strengthening of the audit office's ability to check parties' finances and organizational networks. ${ }^{112}$ In due course, there were further calls that Ibiza had revealed the need for more stringent legislation pertaining to the financing of political parties. ${ }^{113}$

Also noteworthy was a commentary by two lawyers defending the alleged mastermind behind the video recordings. ${ }^{114}$ Concerned by the fact that some media had shifted attention away from what had been said on Ibiza and toward the question of the legality of its publication, the lawyers argued that their client had shown civil disobedience in the public interest by uncovering plans or at least a willingness to alter Austria's media landscape and encourage hidden party financing that threatened democracy. ${ }^{115}$ As this discussion has shown, the ripple effects of the initial revelations had spread far and wide, including, for instance, the Falter's investigations into how the ÖVP, especially though not only, had exceeded its 2017 campaign spending. ${ }^{116}$ By the end of the year, there were indications that the effects of Ibiza were manifesting beyond the predictable circle of political actors and journalistic commentators. When the country's "word," "infamous word," and "infamous phrase of the year" were decided by a sample of 7,500 participating Austrians, the wider resonance of Ibizagate crystallized: "Ibiza" emerged as "word of the year"; Strache's belittling description of what had happened as a fairly harmless "piss-up" (b'soffene G'schicht) as the year's most infamous word; and the previously mentioned "zack, zack, zack" as 2019's infamous phrase. ${ }^{117}$

Few critical voices have commanded as prominent a place as Florian Klenk, chief editor of Falter and the first Austrian journalist to see the full Ibiza recordings prior to the revelations in Süddeutsche Zeitung and Der Spiegel. When called as the first witness to the parliamentary inquiry in June 2020, Klenk dispelled Strache's defense while also placing the scandal in its wider context: Klenk thus declared that the published extracts had, contrary to Strache's oft-repeated claims, not been taken out of context, and that the video showed Strache not intoxicated but engaging in a "corruption dance" that painted a disconcerting picture of the abuse of power in Austria. ${ }^{118}$ Elsewhere, Klenk reflected on what had become fragmented, politically polarizing Ibiza investigations involving two ministries, two departments of public prosecution, and —in the early stages—an investigator who was a member of the ÖVP and a documented Strache sympathizer. This resulted, Klenk argued, in sometimes incoherent investigations, in which questions about the making of the video threatened to overshadow the larger corruption-related issues, and that such incoherence called for political reforms. ${ }^{119}$ Armin Thurnher, Klenk's colleague at Falter, went so far as to argue that "Ibiza" had not been an "embarrassing slipup" but rather revealed deep-seated structural problems in Austria. ${ }^{120}$

\section{Concluding Comments}

Profil described "Ibiza" as a "scandal that has changed Austria." Opposing Strache's relativizing strategy and self-ascribed martyr status, the newsmagazine continued thus:

This video was no fiction, and certainly not the b'soffene G'schicht, into which Strache keeps trying to remold it... Much would have remained hidden without the video's publication: Strache's plans for the betting industry, for the Kronen Zeitung, or the FPÖ's network of associations. The video revealed the deep chasm between portraits of the FPÖ as a clean party fighting for ordinary people against the establishment and Strache's real ambitions, his unscrupulous privileging of personal over

\footnotetext{
112“'Ibiza-Skandal' erhöht Reformdruck," ORF News, 23 May 2019, https://orf.at/stories/3123878/.

${ }^{113}$ E.g., Michael Nikbakhsh,"Zahlen heißt nicht kaufen,” Profil, 1 Sept. 2019, p. 11.

${ }^{114}$ The charge brought against their client concerns the "misuse of recording devices."

${ }^{115}$ Richard Soyer and Philip Marsch, "Ibiza, das war ziviler Ungehorsam," Der Standard, 15 Oct. 2019, https://www.derstandard.at/story/2000109883909/ibiza-das-war-ziviler-ungehorsam?ref=nl.

${ }^{116}$ Armin Thurnher, "Die ÖVP-Files und die Kunst der politischen Umdeutung," Falter, 10 Sept. 2019, p. 5.

117 “'Ibiza' ist das Wort des Jahres," ORF Steiermark, 5 Dec. 2019, https://steiermark.orf.at/stories/3024766/.

118 "Strache bedingt auskunftsfreudig," ORF News, 4 June 2020, https://orf.at/stories/3168353/.

${ }^{119}$ Florian Klenk, "Geheimsache Ibiza," Falter, 5 June 2020, pp. 12-14.

${ }^{120}$ Armin Thurnher, "Wir sind es! Erinnerung an Ibiza," Falter, 15 May 2020, p. 5.
} 
national interests.... His vision for Austria's media landscape oriented itself toward the Hungarian model. $^{121}$

The run-up to, and the early stages of, the parliamentary inquiry have seen significant further developments. Strache's dual strategy of admitting to embarrassing behavior while denying any wrongdoing and claiming a victim status for himself has continued. The FPÖ's estrangement from its former head has reached new extremes, with Herbert Kickl declaring that Strache was now "even more stupid than a year ago." 122 Concurrently, the FPÖ especially and the current opposition more generally have sought to enlarge the circle of culprits for the structural problems unearthed to implicate the ÖVP. The stillunfolding parliamentary inquiry has indeed seen growing animosities between the current government of the ÖVP and Greens, on the one hand, and the opposition comprising the SPÖ, FPÖ, and NEOS, on the other. ${ }^{123}$ The variously drawn, contested, or blurred boundaries, and hence the narrow attribution or expansive deflection of responsibility, respectively, are the quintessential issues at stake in the discursive political field that has opened up since the start of Ibizagate. At the same time, the number of voices calling for far-reaching institutional reforms, in light of what has been discovered since May 2019 , are growing steadily. ${ }^{124}$

This discussion has built upon Foucault and his colleagues' I, Pierre Rivière; there, as in the Ibiza scandal, different subject positions, individual and collective, map onto competing regimes of truth. ${ }^{125}$ Of course, the respective foci and units of analyses lie far apart: Foucault et al. revealed the contested interrelationship between psychiatry and criminal justice in the mid-nineteenth century. The present case study, conversely, has unearthed a multiplicity of "discordant" yet mutually astutely aware and competing voices and "narrative frameworks"126 articulated in the aftermath of Austria's biggest recent political scandal. In both cases, a cacophony of competing truth claims makes seemingly straightforward questions as to what is true or false "undecidable."127 Approaching the issues and materials at hand through such a binary lens would miss the point. Instead, settings such as the one discussed here allow a different form of examination: one focused on the "construction and flow" of competing knowledges. Read in their respective contexts, and nowadays profoundly shaped by the echo-chambers of our digital age, such competing knowledges acquire yet greater methodological relevance as a means for "decipher[ing] the relations of power, domination and contest," in which discourses materialize. ${ }^{128}$

On the level of postfact interpretative struggles, events in Austria since May 2019 have resonated with the (post-)Foucauldian insights summarized earlier. Foucault traced "a case, an affair, an event" that came to be (re)constructed multiple times in the "intersection[s] of discourses" of various "origin[s], form[s], organization and function"; this revealed "a confrontation ... through discourses ... used as weapons of attack and defense in the relations of power and knowledge."129 Similarly, though closer to the context at hand, Pieter Judson has revealed how, in the late-imperial period, "messy events" along the Habsburg Empire's internal language frontiers were seized upon by nationalist

\footnotetext{
${ }^{121}$ Christina Hiptmayr, Michael Nikbakhsh, Christina Pausackl, "Urknalleffekte," Profil, 22 Dec. 2019, pp. 27-28. In addition to Strache's apparent preference for Orbánesque media control, the FPÖ's long-standing pro-Russian positions are worth mentioning: see Herbert Auinger, Die FPÖ: Blaupause der Neuen Rechten in Europa (Vienna, 2017), 127-30; Kurier, "FPÖ-Spitze zu Arbeitsgesprächen in Moskau," 18 Dec. 2016, https://kurier.at/politik/inland/fpoe-spitze-zu-arbeitsgespraechen-in-moskau/236. 473.244 .

${ }^{122}$ Michaela Reibenwein, "Kickl über Strache: 'Noch blöder als vor einem Jahr," Kurier, 19 May 2020, https://kurier.at/amp/ politik/inland/kickl-ueber-strache-noch-bloeder-als-vor-einem-ja.

123“Politgerangel vor nächster Befragung," ORF News, 21 June 2020, https://orf.at/stories/3170475/.

124“Zadic kündigt Gesetzespaket an," ORF News, 17 May 2020, https://orf.at/stories/3166024/; “'Ibiza-Affäre': Transparency fordert weitere Verschärfungen," ORF News, 19 May 2020, https://orf.at/stories/3166233/; Florian Klenk, "Ibiza für Einsteiger," Falter, 17 June 2020, pp. 18-20; “Tanner lässt Kooperationen mit Vereinen prüfen,” ORF News, 22 June 2020, https://orf.at/stories/3170561.

${ }^{125}$ Robert Castel, “Die Ärzte und die Richter,” in Der Fall Rivière, ed. Michel Foucault (Frankfurt, 1973), 279-96.

${ }^{126}$ Brass, Theft of an Idol, 59 .

${ }^{127}$ Alexandre Fontana, "Die Intermittenz der Vernunft," in Der Fall Rivière, 306.

${ }^{128}$ Michel Foucault, "Einführung," in Der Fall Rivière, 11.

${ }^{129}$ Brass, Theft of an Idol, 3 .
} 
activists and the press; "disputed chains of events" were thereby given a nationalist gloss "endowed with propagandistic value by linking them to ... larger narrative frameworks." 130 The point is not that nothing had happened-it had; but its alleged meanings were constructed, claimed, contested, and disseminated after the fact.

When applied to the Austrian contests examined here, such an approach can capture a political field in flux and trace its constitutive and shifting fault lines and divisions. Once again, nationalist frameworks of meaning have played key roles, but certainly not the only ones, as this discussion has shown. In some ways, the fallout of the Ibiza affair can be read as at least a temporary shift away from the nationalist hegemony that was in the process of crystallizing before the scandal broke.

Such a constructivist take does not mean that the facts behind the affair cannot or will not be discovered, let alone that they should not be revealed. The Austrian public deserves nothing less than full disclosure of what happened on Ibiza in 2017, as well as in and beyond the FPÖ's innermost circles before and since. What this analysis reveals, however, is what Georg Simmel ${ }^{131}$ called in a different context an Außerdem: aside from what did or did not occur in and since Ibiza, the discussions analyzed already reveal old and new fault lines, dynamics, antagonisms, and boundaries (re)drawn and contested that both reflect and shape Austria today. My analysis has traced uneasily coexisting, at times outrightly competing, and shifting discursive positions focused on Ibiza, the investigations, and discussions triggered by the scandal. By following argumentative positions over a year, this article illuminates the competing performances that have been rewriting Austria's political landscape since May 2019. The most prominent rhetorical performances have included Strache's initial regret that soon turned into a self-ascribed "victim-cum-martyr-role"; the FPÖ's gradual distancing and eventually seemingly irrevocable rupture from its former head; the Kronen Zeitung's publicly performedand in some quarters publicly doubted-ideological reorientation; the ÖVP's boundary-drawing strategies vis-à-vis the FPÖ (and SPÖ); and the recognition among critical commentators and parts of the opposition ${ }^{132}$ that Ibiza presented opportunities to shift dominant discourses (i.e., away from the renationalization represented by the former ÖVP-FPÖ coalition) and to call for structural changes.

With the fallout to the Ibiza scandal far from settled, this may be the only thing we can say with certainty at the time of writing in June 2020: when viewed through the Foucauldian lens applied in this article, the events that Ibiza triggered cast new light on how political fields change in moments of crisis. ${ }^{133}$ This analysis has followed the competing voices, shifting concerns, and rhetorical-argumentative positions adopted by multiple actors with stakes in the currently unfolding reconfiguration of the political field in question.

Christian Karner is Professor of Sociology at the University of Lincoln, UK. He has published widely on questions of ethnic and national identities in and beyond Austria. His single-authored books include Ethnicity and Everyday Life (2007), Negotiating National Identities (2011), and Nationalism Revisited: Austrian Social Closure from Romanticism to the Digital Age (2020). Christian's co-edited collections have included The Use and Abuse of Memory (2013), The Commonalities of Global Crises (2017), National Identity and Europe in Times of Crisis (2017), and (Kon-)Texte des Politischen (2018).

\footnotetext{
${ }^{130}$ Judson, Guardians, 177-79.

${ }^{131}$ Georg Simmel, Soziologie (Frankfurt, 1992 [1908]), 52.

${ }^{132}$ After the constitutional court declared that a parliamentary inquiry committee on Ibiza would be given a broadened scope, an SPÖ politician declared that particular attention would be paid to aspects "uncomfortable" to the ÖVP; see "SPÖ und Neos drängen auf raschen Start,” ORF News, 4 Mar. 2020, https://orf.at/stories/3156582.

${ }^{133}$ Bourdieu, Outline, 167ff; Karner, Nationalism Revisited, $140 \mathrm{ff}$.
}

Cite this article: Karner C (2021). "Ibizagate": Capturing a Political Field in Flux. Austrian History Yearbook 52, $253-269$. https://doi.org/10.1017/S0067237820000557 